\title{
Chvála vyprávění aneb narativní stezky výchovy k hodnotám
}

Helena Zbudilová

\author{
„Chceš-li někomu ukázat jeho tvár̆ a probudit jej ze spánku, \\ musíš jeho tvár odít v príběhy" \\ Nachman z Braslavi
}

Stávající číslo časopisu Caritas et Veritas je tematicky zaměřeno na Hodnoty ve výchově. Toto téma bylo pro svou aktuálnost vyłyčeno ve spolupráci s katedrou pedagogiky TF JU $\vee$ Č. Budějovicích. Téma vede autorku článku k představení konkrétního zpưsobu uvažování humanitních věd $v$ oblasti reflexe skutečnosti vyprávěných príběhů. Samotný název textu naznačuje, že jeho cílem není naratologická studie, nýbrž článek zdưrazňující význam narativity v pedagogickém procesu. „Chvála vyprávění" předjímá pozitivní tok textu a ztotožnění autorky s "narativními stezkami“, které chápe jako jednu z cest výchovy k hodnotám. V textu rezonuji myšlenky vybraných osobností (především z oblasti filosofie, literární vědy, pedagogiky a psychologie), které se vztahují $k$ problému krize hodnot $v$ současné společnosti a úloze narativity ve vztahu $k$ cíleně zaměřené výchově a vzdělávání $k$ hodnotám. Text zdưrazňuje pozitiva „,narativních stezek" výchovy k hodnotám, protože vyprávění príběhů má v současném pedagogickém diskurzu své místo.

\section{Krize hodnot v současné společnosti}

V postedukační době (pojem R. Palouše) ovlivňované duchem konzumerismu, který existuje napřič kulturami a státy, vnímáme, že současný způsob života je veden bez valných spirituálních a jiných hodnot. Ty se z lidského života vytrácejí. Převládají hodnoty materiální povahy (hodnoty utilitární) spojené s touhou po vysokém životním standardu, penězích, osobní prestiži a úspěchu. Společenská a kulturní realita proniká stále intenzivněji do oblasti výchovy bez ohledu na rozvoj citové a mravní složky osobnosti. Vladimír Spousta ve studii Krize současné společnosti a proměny hodnot na prèlomu tisíciletí doporučuje posilovat orientaci na duchovní hodnoty, na etické a estetické otázky. ${ }^{1}$ Zapomínáme, že s ostatními lidmi nás spojuje sdílení společných životních hodnot a vzájemnosti, tzv. spolučlověčenství. Jan Patočka konstatoval, že v postmodernismu člověku chybí opěrný bod, něco trvalého a obecně platného. Oním opěrným bodem by mohl být právě návrat k „žitým“ hodnotám prostřednictvím „výchovy k hodnotám".

Pro svět počátku 3. tisíciletí zůstávají v platnosti slova Ericha Fromma o moderní společnosti jako o „vědeckotechnicky přesycené“3 a ,lidsky podvyživené“ . ${ }^{4}$ Dochází k zvěcňování člověka, odcizující individualizaci a odosobňování mezilidských vztahů. Člověk se stává objektem pod

1 Srov. Vladimír SPOUSTA, Krize současné společnosti a proměny hodnot na přelomu tisíciletí, Pedagogika 3/2008, roč. LVIII, s. 248.

2 Srov. Albert SCHWEITZER, Z mého života a díla, Praha: Vyšehrad, 1974, s. 193.

3 Erich FROMM, Mít, či být?, Praha: Aurora, s. 13.

4 Tamtéž, s. 18. 
různými kódy a čísly, i jeho duše se zvěcnila. Jeho čas je dobou displejů a obrazovek, všeobecné virtualizace života jako nekonečné show s všudypř́tomnou reklamou. V duchu orwellizace životního stylu se člověk stává otrokem mobilů a počítačů, nad jeho životem bdí „Velký bra$\operatorname{tr}^{\prime \prime}$. Ve věku informatiky a světě médií a internetu se bytí proměnilo v dění - začarovaný kruh práce, užívání a spotřebovávání. ${ }^{5}$ Člověk utíká sám před sebou a zahlušuje se prací a zábavou. Postmoderní gnoseologický a hodnotový relativismus a pluralita vedou k roztřištěnosti a eklekticismu. Pravda se stává prázdným pojmem, právo a spravedlnost nástrojem různých interpretací. Jde o rozklad hodnot, řádu, pravdy a celků ve prospěch částí. ${ }^{6}$ Tato doba krize hodnot (v krajní podobě hodnotového a etického nihilismu) je též krizí vyprávění. Postmoderní pseudosvobodný člověk si názory netvoří, ale vybírá. Podle Jana Poněšického tento člověk funguje v mnohačetných identitách, a nemá-li ideály, nemusí cítit vinu ani stud, že se jim zpronevěřil. ${ }^{7}$ Stylizuje se do pozice diváka, vnějšího pozorovatele, nezaujatého arbitra. Člověk je schopen v duchu postmoderní flexibility vždy nově převyprávět svůj dosavadní život. Jeho iluzivní svět deformované skutečnosti je světem vyprázdněné symboliky a ztráty dějinného vědomí; světem zmrzačeným absencí posvátného, rezignací na rozum i víru. Chybí vhled do celku, všemu vládne jen specializace. Realita není vnímána jako soudržný koherentní celek, ale jako „skrumáž nahodilých a proměnlivých událostí ${ }^{8}$ Dochází k neustálému přehodnocování hodnot, jež ve svém důsledku vede k trvalé hrozbě ztráty integrity. Každá absolutní hodnota může být demaskována jako absurdní, zavánějící totalitou či rozpadlou metanarací. ${ }^{9}$ Věčné a tradiční hodnoty jsou zpochybňovány a relativizovány, často se ztrácejí v záplavě lákavých nabídek života bez závazků a zodpovědnosti. ${ }^{10}$ Zůstala jen jediná neotřesitelná hodnota - trh. Zdá se, že postmoderní svět chápající hodnoty jako otevřené struktury vždy připravené k přehodnocení je ve své podstatě rezignací na lidství, svobodné rozhodování a svobodnou zodpovědnost. ${ }^{11}$ Zygmunt Bauman dokonce vyjadřuje obavy z budoucího možného přechodu od typu člověka-zahradníka k člověku-lovci. Vyjevuje se nám obraz člověka rezignujícího, přeŽívajícího v lhostejné prázdnotě svého bytí, kde není Bůh ani člověk. Podle Jana Poněšického „existenciální vrženost člověka do potenciální naprosté svobody spojená s úzkostí a nejistotou je v dnešním světě protiobsazena opakem - spokojeností a přesvědčením, že nikdo nemá právo cokoli předepisovat, moralizovat či usměrňovat ${ }^{\prime \prime}{ }^{12}$

\section{Charakteristika narativity}

Vyprávění - narativita - je základním lidským vztahem ke skutečnosti. Nic na světě, žádný člověk, žádná věc nemůže být bez svého příběhu. Narativizace je proces, v němž se člověk zmocňuje světa, pokouší se jej poznat. Základní, původní a společnou podobou lidského myšlení je vyprávění příběhů. Jak pravil Gregory Bateson: „My lidé myslíme v příbězích.“13 Náš svět je utkán z příběhů, náš vlastní život je příběh. Narativní způsob sdělení a chápání je pro nás zcela přirozený. Člověk sám sobě obvykle rozumí v souřadnicích příběhu. Vyprávím, tedy

\footnotetext{
5 Srov. Anna HOGENOVÁ, Postmoderna a fenomenologie, in: Člověk a jeho postavení ve světě, Jan PONĚŠICKÝ, Praha: Triton, 2006, s. 181.

6 Srov. Jan PONĚŠICKÝ, Člověk a jeho postavení ve světě, s. 108.

7 Srov. tamtéž, s. 22.

8 Jan HÁBL, Pedagogika a metanarace: pro a navzdory postmoderní situaci, in: Pedagogická komunikace v didaktických, sociálních a filozofických souvislostech, Hradec Králové: Gaudeamus, UHK, 2009, s. 33.

9 Srov. Marek FAJFR, Hodnoty jako výzva současné výchovy, in: Hodnoty ve výchově, umění a sportu. Sborník z mezinárodní konference konané na PedF UK Praha, eds. Anna HOGENOVÁ - Naděžda PELCOVÁ, Praha: UK v Praze, PF, 2008, s. 84.

10 Srov. Jan PONĚŠICKÝ, Člověk a jeho postavení ve světě, s. 163.

11 Srov. Marek FAJFR, Hodnoty jako výzva současné výchovy, s. 81.

12 Jan PONĚŠICKÝ, Člověk a jeho postavení ve světě, s. 21.

13 „We think in terms of stories." Gregory BATESON, Mind and Nature - a neccesary unity, Toronto, New York, Londýn, Sidney: Bantam, 1980, s. 14
} 
jsem. Ale jak jsem? Jaká hodnotová orientace určuje můj př́iběh v kontextu světa, do jehož metanarace jsem heideggerovsky „vržen“? Proměňující moc př́iběhů se může stát klíčovým prvkem didaktického procesu při formování osobnosti a identity žáka. Slovy Jana Hábla: Je potřeba učit (se) př́iběhem. ${ }^{14}$ Narativní metoda představuje výsostnou cestu výchovy $\mathrm{k}$ hodnotám. Skrze ni lze žáky učit hledat, nalézt a stvořit svůj vlastní příběh. Dobrý příběh, který dává smysl.

Vyprávěním se lze podílet na bytí či se jej dotýkat; „vyprávěje bydlí člověk“ ${ }^{15}$ Jako homo narrans vyprávíme příběhy, a tak dáváme světu řád. Podle Jiřího Trávníčka představuje vyprávění příběhu jazykové, sociální a prostorové myšlení: „Myslíce narativně, pohybujeme se v situacích, myslíce logicky, jsme odkázáni na pojmy. " ${ }^{16}$ Autor zdůrazňuje empatickou a mimetickou funkci příběhu a zmiňuje jeho "heuristickou potenci“: „V příběhu žijí, jednají, přemýšlejí a projevují se všemi vlastnostmi a schopnostmi postavy, s nimiž konfrontujeme vlastní existenci. Příběhy obsahují modely jednání, které představují reálnou možnost nápodoby. Mohou se stát ,zjevením', které slouží k následné refiguraci či převyprávění svého vlastního příběhu." ${ }^{17}$

Jak uvádí J. Trávníček, vyprávění nám dává možnost vystoupit ze sebe a podívat se na sebe jako na něco jiného. ${ }^{18} \mathrm{~V}$ posledních desetiletích se humanitní vědy zabývají problematikou příběhu. Ve filosofii, teologii, psychologii, literární vědě i v kulturní antropologii se od druhé poloviny 20. století stal příběh a jeho vliv na člověka jedním z hlavních témat odborné diskuse. V teologické oblasti připomeňme narativní teologii a její klíčové představitele, jako jsou např. G. Lindbeck, H. W. Frei, S. Hauerwas, K. Barth; ${ }^{19}$ z českých odborníků M. Altrichter. ${ }^{20}$ Pavel Hošek v knize Kouzlo vyprávění (2013) nabízí pohled na př́iběh z hlediska hermeneutiky, literární teorie, hlubinné psychologie a konkrétní nábožensko-kulturní tradice, kde vyprávění příběhů hraje rozhodující roli. Biblické příběhy Starého a Nového zákona a fiktivní vyprávění krásné literatury „projektují svět“ a nesou v sobě konkrétní porozumění lidskému životu. Mohou mít objevitelskou a vpravdě motivující moc. ${ }^{21}$ Jde o vlastní vstoupení do příběhu a zvnitřnění sdíleného narativního obrazu světa. Příběhy mohou mít rozhodující vliv na zdárný proces postupného duševního zrání jednotlivců, a tak se využívají v psychologii při tzv. narativní psychoterapii. ${ }^{22}$ Smyslem narativní terapie je posun od příběhu, kterému dominuje problém, $\mathrm{k}$ prríběhu alternativnímu. ${ }^{23}$

Z pedagogického hlediska je žák jako posluchač či čtenář vyzýván, aby angažovaně vstoupil do interpretace vyprávěného nebo čteného, tvořil si své fiktivní světy, odhaloval archetypy v postavách, dospíval k sebetranscendenci. Lidským úkolem je vnímat, setkávat se, rozumět a jednat. ${ }^{24}$ Úkolem učitele je probudit žáky z ontologické letargie, naučit je odemykat příběh a odkrývat jej jako vztah k bytí. ${ }^{25}$ Žák vystavený moci příběhu myslí, cítí, prožívá, identifikuje se, přijímá informace, hodnotí. Vlastní identitě rozumí zpravidla jakožto příběhu. Porozumět

14 Jan HÁBL, Učit (se) př́během, Brno: Host, 2013, s. 7.

15 Srov. Daniela HODROVÁ a kol., Na cestě ke smyslu. Poetika literárního díla 20. století, Praha: Torst, 2001, s. 785.

16 Jiří TRÁVNíČEK, Vyprávěj mi něco. Jak si děti osvojují př̌iběhy, Praha - Litomyšl: Paseka, 2007, s. 16.

17 Tamtéž, s. 51.

18 Srov. tamtéž, s. 52.

19 Doporučujeme např. Jaroslav VOKOUN, K rekonstrukci teologie po konci novověku. Postkritický př̌stup, Č. Budějovice: Jihočeská univerzita v Č. Budějovicích, 2008.

20 Michal ALTRICHTER, „Duchovní a "duševni“. Př́spěvek z pohledu teologie narativní, Olomouc: Centrum Aletti, Velehrad: Refugium Velehrad-Roma, 2003.

21 Srov. Pavel HOŠEK, Kouzlo vyprávění, Praha: Návrat domů, 2013, s. 18.

22 Srov. tamtéž, s. 92.

23 Srov. Jan HÁBL, Učit (se) príběhem, s. 49.

24 Srov. Zdeněk KRATOCHVÍL, Filosofie živé př̌rody, Praha: Herrmann a synové, 1994, s. 68.

25 Zdeněk KRATOCHVÍL, Výchova, ž̌ejmost, vědomí, Praha: Herrmann a synové, 1995, s. 55. 


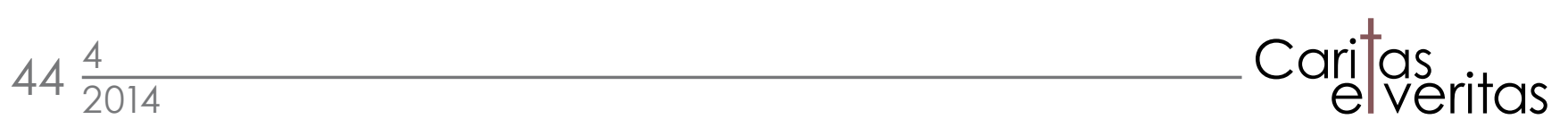

sám sobě tedy znamená porozumět si tváří v tvář příběhům. Skrze svou narativní organizaci dostává život tvar, řád, souvislost, směřování a smysl. Paul Ricoeur zabývající se fenomenologií vyprávění dospívá k přesvědčení, že mezi „být“ a „být řečen“ je jakási původní, intimní vzájemnost. ${ }^{26}$

\section{Narace a mýtus}

Skutečnost má povahu vyprávění a bytí představuje tok děje. Lidská přirozenost jako taková je zakotvena v mytickém světě. ${ }^{27}$ Mýtus poskytoval klíč k porozumění světu, kde se skutečnost vyprávěla, kde se obraz celku světa vyjadřoval formou příběhu. ${ }^{28}$ Jednota světa byla deklarována slovem kosmos. Člověk byl přizýván k účasti na velkém dramatu života, jeho všední každodennost byla těsně spjata s kosmickým děním (s celkem světa, pravdou a řádem). Mytický čas byl dobou zrodu archetypů lidství, vedl člověka k rituálnímu jednání. Mytické myšlení se hodnotově a eticky vyznačuje proměnou chaosu v kosmos, stavíc člověka před nárok proměny. ${ }^{29}$ Mýtus má hodnotový, mravní a existenciální obsah; jeho výchovný význam pak spočívá v paradigmatech (vzorových situacích a modelech jednání). ${ }^{30}$

Podle filosofa Jana Patočky je „mysteriem lidské existence v mýtu ,idea fronesis', spolehnutí se na sebe. V tom spočívá ,vina člověka' a znamená to, že člověk není vinen; jeho bytostným určením je, že je vinou. “31 Výchovným smyslem mýtu je přivedení člověka k poznání, že on sám je vybočením, rozkolem a zmarem, nenajde-li cestu zpět pod zákon, řád a vyšší smysl. ${ }^{32}$ Cílem výchovy je vést zranitelnou a zároveň statečnou lidskou bytost $\mathrm{k}$ účasti na světě a životě a na jeho pokračování. Mýtus vedle poslušnosti tradici a zákonu zároveň formuje úžas vůči posvátnu. ${ }^{33}$

Když lidé přestali věřit v kosmogonickou a historickou skutečnost svých příběhů, mýtus nahradila filosofie, svět vládnoucího logu. Podle Mircea Eliade je však „,málo pravděpodobné, že by se nějaká společnost mohla zcela oprostit od mýtu, nebot' základní rysy mytického chování - příkladný vzor, opakování, zrušení světského času a splynutí s prvotním časem - přinejmenším první dva z nich, jsou nerozlučně spjaty s každým lidským údělem“. ${ }^{34}$ Mytická mentalita není věcí minulosti, nýbrž je stále přítomna vrstvou současného prožívání, chápání a myšlení. Soudobá výchova se snaží člověka z rozsedliny mezi mýtem a logem vyvést do oblasti logu. Základem problémů se stává pojetí filosofie a vědy jako negace mýtu. ${ }^{35}$ Skrze umění lze znovuprocitnout $\mathrm{k}$ příběhům a tajemnému kouzlu mytopoetických obrazů. Tyto obrazy a příběhy oproštěné od světa odcizující objektivity mohou podle Zdeňka Neubauera poskytnout možná i pravdivější a srozumitelnější přístup ke světu než vědecká faktografie. ${ }^{36}$ Podle Jana Patočky existuje v každém uměleckém díle „emocionální dominanta, která funguje jako ucelující činitel

\footnotetext{
26 Paul RICOEUR, Soi-même comme un autre, Paris: Sauil, 1990, s. 69. V říjnu 2015 nakladatelství OIKOYMENH vydá český překlad O sobě samém jako o jiném.

27 Srov. Zdeněk NEUBAUER, Do světa na zkušenou čili O cestách tam a zase zpátky, Praha: Straky na vrbě, 2010, s. 41.

28 Srov. Naděžda PELCOVÁ, Filozofická a pedagogická antropologie, Praha: Karolinum, 2000, s. 17.

29 Srov. Naděžda PELCOVÁ, Vzorce lidství, Praha: Portál, 2010, s. 25.

30 Srov. tamtéž, s. 21.

31 Jan PATOČKA, Pravda mýtu v Sofoklových dramatech o Labdakovcích, in: Divadelní program Divadla za branou, Sofokles: Oidipus-Antigone, Praha, 1971, nestránkováno.

32 Srov. Naděžda PELCOVÁ, Filozofická a pedagogická antropologie, s. 20.

33 Srov. Jan BOUZEK - Zdeněk KRATOCHVÍL, Od mýtu k logu, Praha: Herrmann a synové, 1994, s. 58.

34 Mircea ELIADE, Mýty, sny a mystéria, Praha: OIKOYMENH, 1998, s. 20.

35 Srov. Zdeněk KRATOCHVÍL, Výchova, zřejmost, vědomí, s. 94.

36 Srov. Zdeněk NEUBAUER, Do světa na zkušenou čili O cestách tam a zase zpátky, s. 68.
} 
a příběh tak působí na člověka intenzivněji než jakékoli racionální vysvětlení či rada“ ${ }^{37}$ Těžiště soudobého myšlení spočívá $\mathrm{v}$ levé mozkové hemisféře, $\mathrm{v}$ racionálním uvažování. Pravá hemisféra vnímá, chápe a vyjadřuje skutečnost globálně, esteticky, hodnotově. Je bezprostředně vystavena účinku symbolů, obrazů, př́běhů. ${ }^{38}$ Literární text umožňuje filosofům-hermeneutikům vstupovat do konkrétních příběhů s přesvědčením, že interpretace jako akt osobního setkání s dílem kultury je přednější než jakékoli popisy, exegeze a analýzy ${ }^{39} \mathrm{~V}$ ricoeurovské hermeneutice tvoři texty kultury, nekonečného množství symbolů, nástroj naší existence a touhy bytí. Proto tato filosofie tolik věři krásné literatuře a jejím příběhům..$^{40}$

V archaických dobách převládala mytická vyprávění a narativní látky kódující exemplární modely lidských činností. V pokročilejších kulturách lze hovořit o celostním sdíleném jazykovém obraze světa, který má rovněž narativní strukturu. Jedná se o tzv. velký př́íběh, Př́iběh, jenž podle Pavla Hoška "definuje a traduje sdílený obraz reality“. ${ }^{41}$ Metanarace představuje uměle utvářené "velké vyprávěni“", které chce pod jednu střechu přenést všechny jednotlivé mytické zkušenosti. Stává se předpokladem vzniku filosofie nebo "světového názoru“". ${ }^{42} \mathrm{Jan}$ Hábl dospívá k přesvědčení, že metanarace po celá staletí zajišt'ovaly integritu lidských pospolitostí a smysluplnost prožívané reality. Každá kultura byla podle něho semknuta kolem př́iběhu, který byl společně sdílen, tradován a předáván. ${ }^{43}$ Př́iběh osmysloval všednodennost a globálně vysvětloval skutečnost. Podle Pavla Hoška je narativní identita společenství určena sdílenou pamětí a sdílenou nadějí, ponořením do společně recitovaného příběhu. Jednotlivé důležité příběhy jsou v rámci konkrétní kulturní či náboženské tradice zřetězeny v jeden celostní „veliký príběh“ či „,velký kód“. ${ }^{44}$ Jan Hábl vymezuje tři základní metanarace - moderní příběh pokroku autonomního racia, pre-moderní prúběh transcendentně zakotvených dějin spásy (křest'anství) a př́iběh dějin seberozvíjení ducha (metafyzika). ${ }^{45} \mathrm{~J}$. F. Lyotard v knize Postmoderní situace (1993) rozlišuje metapř́iběhy ve třech oblastech - v osvícenském projektu emancipace lidstva, v idealistické teleologii ducha a historizující hermeneutice smyslu. Doba postmodernismu podle něho přináší konec velkým př́běhům. ${ }^{46}$

V postmoderní době s paradigmatickou změnou myšlenkového klimatu dochází podle J. F. Lyotarda ke krizi důvěry v metanarace, jež se díky sklonu k totalizování (diktátorství) stávaly exkluzivním výkladem skutečnosti a nástrojem moci (kolonialismus západu, komunismus východu). ${ }^{47}$ Jednotný a univerzálně platný obraz, který zprostředkovávaly autority jako vědci, kněží, intelektuálové aj., byl nahrazen pluralitou obrazů a řečových her. ${ }^{48}$

Postmoderní pluralitu chápe J. F. Lyotard jako určitou perspektivu, která počítá s rozmanitostí. Postmoderní společnost již tedy nežije pro velký celek, velkého hrdinu, velkou ideu. S prosazením liberálního kapitalismu a vědecko-technické a informační revoluce po 2. světové válce se hroutí metapř́běh, a znejist'uje se tak centralizující střed lidských úvah. Pro postmo-

\footnotetext{
37 Jan PATOČKA, Umění a čas, Praha: OIKOYMENH, 2004, s. 304.

38 Srov. Zdeněk NEUBAUER, O Sněhurce aneb cesta za smyslem bytí a poznání, s. 13.

39 Srov. Zofia MITOSEKOVÁ, Teorie literatury, Brno: Host, 2010, s. 415.

40 Srov. tamtéž, s. 418.

41 Pavel HOŠEK, Proměňující moc příběhu, Církevní dějiny 5/2010, s. 88.

42 Vladimír MACURA - Alice JEDLIČKOVÁ, Průvodce po světové literární teorii 20. století, Brno: Host, 2012 , s. 493.

43 Srov. Jan HÁBL, Pedagogika a metanarace: pro a navzdory postmoderní situaci, s. 31.

44 Pavel HOŠEK, Proměňující moc příběhu, s. 90.

45 Srov. (C) Paidagogos, 2012, Jan HÁBL, Aby člověk neupadal v nečlověka aneb o Komenském a smyslu pedagogického počínání (online),

dostupné na: http:/ / www.paidagogos.net/issues/2013/2/article.php?id=5, citováno dne 17. 2. 2014.

46 Jean-François LYOTARD, O postmodernismu. Základní filosofické texty, Praha: Filosofický ústav AV ČR, 1993, s. 143.

47 Srov. tamtéž, s. 102.

48 Srov. Vladimír MACURA - Alice JEDLIČKOVÁ, Prưvodce po světové literární teorii 20. století, s. 493.
} 
dernu je příznačný proces dekonstrukce, zkoumání textu ze všech možných perspektiv. Je vyloučeno přisuzovat jakémukoli textu základní či konečný význam. Nedůvěra v metavyprávění je nahrazena důvěrou v polyvyprávění (multivyprávění). Václav Bělohradský v knize Mezi světy E mezisvěty (1997) konstatuje, že byly rozevláty historické světy. Obraz platónské jeskyně nahrazuje tento filosof podobenstvím o chladných mezisvětech, v nichž jsme „rozdělali ohně, $\mathrm{k}$ nimž přisedáme, posloucháme a vyprávíme ${ }^{\prime 4}{ }^{49}$ Metaforicky je toto vyprávění u ohně filosofií. Současnost se rozpadla na hledající individua a jednotlivé životní příběhy. Jako by postmoderní doba zoufale postrádala svůj vlastní příběh.

\section{Narativní stezky výchovy k hodnotám}

Současná škola se nachází v post-příběhové situaci, je školou bez metanarace. Jak uvádí Jan Hábl v knize Učit (se) př́během, škola dřive dávala smysl bud' na pozadí pokroku, nebo věčnosti. Tento smysl se však postmodernitou ruší. Škola přestala být garantem výchovně-formativní role ve společnosti, přestala být klíčovým prostředkem ke sdílení meta-příběhu..$^{50}$ Ztracenou metanaraci nahradila masmédia, žák se stal klientem pragmaticky připravovaným k uplatnění na trhu práce. J. Hábl přirovnává školu bez metanarace k divadlu zbavenému divadelní hry. Chybí mythos - děj a pointa. ${ }^{51}$ Taková školní výchova sice přivádí žáka k úspěšnosti, nepřivádí jej však domů - k poznání sebe sama a svého smyslu v řádu bytí. Největší nebezpečí skýtá oddělení žáků od přirozenosti, od jejich vlastního lidství a od zkušenostní povahy př́rody. Tento defekt lidství je dnes ve společnosti všudypřítomný. Hledání přirozeného světa bylo příznačným rysem filosofie J. Patočky. Zdeněk Kratochvíl v knize Výchova, zřejmost, vědomí (1995) používá termín „denaturace“ př́irody, člověka, společnosti, světa.52 Výrazným způsobem toto téma uchopil též v knize Filosofie živé př́rody (1994): „Denaturované substance mají tu moc, kterou po nich chceme, a práce s nimi je tudíž bezpečná, ale příroda a přirozenost (natura) byla zbavena sebe sama, svého vnitřního života a spontaneity. " ${ }^{33}$ Rozšiřuje se umělé životní prostředí, dílo člověka jako totální artefakt vytváří nový druh přírody. Dochází ke zpředmětňování světa, vše může degradovat v pouhý objekt. Člověk zažívá aranžovanou a deformovanou skutečnost, obývá iluzivní pseudoautentický globální svět. Profanace „lidského pobytu“ je často provázena pocitem duchovní prázdnoty. Clověk ztrácí schopnost zažít úžas, navázat vztah úcty. V situaci celosvětové hodnotové krize, kdy vše je převáděno na tržní hodnotu, by současná škola měla opět najít svou duši a vzepřít se beznarativní naraci trhu i obecně přijímanému diktátu masmédií.

Postmoderní život v pluralitě hodnot nesmí představovat nezávazný život. Výchova v 21. století tak stojí před nesnadným úkolem. Věda a křest'anství čelí bezbřehému relativismu na jedné straně a na straně druhé krajnímu fundamentalismu a sektářství. Postmoderní pluralita konfesijní a spirituální, prolínání světů a kultur, neexistence středu jako centra hierarchického uspořádání společnosti a obraz člověka uzavřeného v postmoderní jeskyni se svým subjekt-objektovým myšlením, to vše je výzvou pro současnou pedagogiku. Jakými cestami se vydat? Jednou z cest humanizačního úsilí současné pedagogiky je rehabilitace narativity v didaktickém procesu. Jan Hábl v knize Učit (se) př́během (2013) navrhuje v tomto smyslu zavedení tzv. didaktické narativizace - zpříběhovatění. ${ }^{54}$ Tento metodický princip představuje využití

49 Václav BĚLOHRADSKÝ, Mezi světy \& mezisvěty: reloaded 2013, Praha: Novela bohemica, 2013, s. 34.

50 Srov. Jan HÁBL, Učit (se) př̌během, s. 63.

51 Srov. tamtéž, s. 65.

52 Srov. Zdeněk KRATOCHVÍL, Výchova, zřejmost, vědomí, s. 149.

53 Zdeněk KRATOCHVÍL, Filosofie živé prírody, s. 19.

54 Srov. Jan HÁBL, Učit (se) príběhem, s. 67. 
příběhu v pedagogické praxi v rovině psychologické a filosofické v rámci konkrétních oborových didaktik. Autor zároveň vyzývá k rehabilitaci metanarativního diskursu: „Současná pedagogika by měla hledat takovou metanaraci, která by veškerá dílčí didaktická vyprávění činila autentická a legitimní. "55 Škola podle něho nesděluje pouze „neutrální“ fakta, ale též jejich interpretační rámce. Dílčí informace a události řadí do velkého "syžetu“", který určuje jejich význam - nejen ve smyslu hermeneutickém, ale též etickém. ${ }^{56}$ Podle Marka Fajfra lze výchovu založit na kontinuálním vyprávění příběhů jako „příběhů ve smyslu neuzavřených textů, ve smyslu řeči, která se neustále vypravuje v tisících variací“ ${ }^{\prime 5}{ }^{5}$

Dynamičnost př́iběhů by podle jeho názoru měla odpovídat funkční hodnotě současného vzdělání a výchovy vyjádřené klíčovými kompetencemi. Ve školách se dnes málo vypráví, předávají se především poznatky. Zdeněk Kratochvíl v této souvislosti připomíná Platónův ironický výrok o vkládání vědomostí do pasivní duše jako o „vkládání zraku do slepých oči““ ${ }^{58}$ Škola by měla pomocí příběhů probudit žákovu duši, zapálit v ní oheň tak, aby se žák naučil "žít ze svého pramene“, žít v autenticitě svého bytí. Měla by být skutečným prostorem živého setkávání tváří $\mathrm{v}$ tvář $\mathrm{s}$ učitelem a textem $\mathrm{v}$ ryzím autentickém dialogu při společném hledání otázek a odpovědí. Základem pro dialog je zároveň potřeba sebereflexe "očima druhých". Učitel a jeho životní př́iběh, odrážející se v jeho hodnotové orientaci a komplexnosti jeho osobnosti, v jednotě slov a činů, v duchu klasického "Exempla trahunt", sehrává ve výchovně-vzdělávacím procesu stěžejní roli. V současném školství je potřeba reflektovat pluralitu bytí a zároveň smysl pro nekategorizovatelné lidské hodnoty - pro zkušenostní poznání a nezištnou lásku. ${ }^{59}$

Výzva Jana Hábla k hledání metanarace pro současnou postmoderní pedagogiku postedukační doby není voláním ojedinělým. Celý vzdělávací sektor potřebuje nově definovat svou identitu. ${ }^{60} \mathrm{I}$ přes značné úsilí o pedagogickou humanizaci školství zůstává škola stále „bytostně funkcionalistickou“ a selhává v kultivaci „celého člověka“. ${ }^{61}$ Výchova by měla rozvíjet schopnost logicky myslet a zároveň vnímat mýtus. $\mathrm{V}$ zásadě jde o nasměrování mysli ke svému zdroji, ideji dobra, skrze chápání př́itomnosti jako brány k věčnosti nebo brány k osvícené budoucnosti. V prvním př́ípadě je pozváním k návratu k mysterijním kořenům víry, k pojetí člověka jako imago dei v tradiční biblické naraci, jako bytosti stvořené pro bytostný vztah s Bohem. Člověk má být svým charakterem reflexí Božího charakteru, tzn. odrazem největšího možného myslitelného dobra. ${ }^{62}$ Metanarace nesoucí kristovský př́iběh mučednické lásky ústí v transcendentně zakotvené dějiny spásy. Znamená přijetí evangelia jako dobré zprávy a desatera jako křest́ansko-etického kodexu. V druhém případě je potřeba vycházet z předpokladu, že svět má smysl a řád, že člověku je dáno místo na tomto světě a že běh světa směřuje k pokroku. Předpokladem budoucnosti je hodnotová orientace zaměřená na trvale udržitelný život, na schopnost člověka vnášet řád do porušeného světa. V současnosti je nejaktuálnějším „morální pokrok“, jenž záleží na rozšiřování spolucítění. ${ }^{63}$ Hodnoty představují opěrné body našeho života. Každý člověk hledá etický ideál jako oporu a v př́iběhu svého života jej konstruuje. ${ }^{64}$

55 Tamtéž, s. 69.

56 Srov. tamtéž, s. 68.

57 Marek FAJFR, Hodnoty jako výzva současné výchovy, s. 86.

58 PLATÓN, Ústava VII, Praha: Svoboda, s. 518.

59 Srov. Zdeněk KRATOCHVÍL, Výchova, zřejmost, vědomí, s. 12.

60 Srov. (C) Paidagogos, 2012, Jan HÁBL, Aby člověk neupadal v nečlověka aneb o Komenském a smyslu pedagogického počínání.

61 Jan HÁBL, Lekce z lidskosti: Antropologické inspirace z díla Jana Amose Komenského, Pedagogická orientace 1/2010, s. 6.

62 Srov. tamtéž, s. 10.

63 Srov. Jan PONĚŠICKÝ, Člověk a jeho postavení ve světě, s. 97.

64 Srov. Miloslava BLAŽKOVÁ, Odysseovy cesty od Homéra k postmoderně, in: Éthos ve výchově, umění a sportu, eds. Naděžda PELCOVÁ Anna HOGENOVÁ, Praha: PedF UK, 2009, s. 189. 
Podle Jana Sokola musí člověk hodnotu „zahlédnout, vydat se za ní a vytrvat - a to všechno sám“. ${ }^{65}$ Zároveň spolu s ostatními „tká společný příběh“. Vůle konat dobro, jež je spojujícím článkem obou zmiňovaných metanarací, je královskou korunou života svých nositelů.

Ve své př́imluvě za hledání velkého příběhu vyzývá Jan Hábl k pokání, odvaze a víře při hledání pevného bodu, na němž lze stavět pedagogický dům. ${ }^{66}$ Bez ideálna nelze budovat reálno. Život je hledání, bytí na cestě, vztahovost; svět pak přirozeným prostorem sebeproměny. Postmodernismus si nedělá nárok na budoucnost, přítomnosti nic nepředepisuje. Konstatovali jsme, že postmoderní doba jako by postrádala svůj vlastní př́iběh. Avšak neexistuje narace bez metanarace. Každý malý př́iběh je vyprávěn na pozadí velkého příběhu. A tedy i postmoderní příběh, který vypráví o nedůvěře $v$ jakýkoli příběh, je ve skutečnosti metapříběhem. Smysl soudobého ateismu, v němž je odklon od Boha v osobní rovině paralelním s jinou formou ateismu - s odcizením se sobě samým -, je v jeho překonání. Sdílíme názor Zdeňka Neubauera, že smysl postmodernismu se vyjevuje jeho začleněním do společného příběhu dějin spásy. ${ }^{67}$

Úkolem hodnotové výchovy (hodnotové pedagogiky) je kultivovat smysl pro hodnoty, naučit preferovat hodnoty věčné před těmi dočasnými, naučit žít plně v rámci svých možností. Filosof Jan Patočka definoval cíl života jako „život sám, jasnost, přicházení k sobě samotnému, nahé postavení jsoucna, žití v autenticitě oproti rozptýlenosti ,veřejného anonyma', jde o to nechat se oslovovat lidmi i věcmi, o vyjevování" ${ }^{68}$ Vše kolem nás má ${ }^{69}$ epifanickou hodnotu a možná právě současná postmoderní doba bezbřehé plurality představuje tu pravou příhodnou chvíli ke zjevení Pravdy a pro následnou paradigmatickou změnu, průlomovou proměnu společnosti. ${ }^{70} \mathrm{~V}$ lůně postmoderní společnosti sekularizovaných hodnot vzrůstá touha po něčem absolutním a vznešeném. Nejvyšší triáda hodnot Pravdy, Dobra a Krásy je věčnou výzvou člověku.

\section{Závěr}

Ve školství by primárně nemělo jít o to, co si žáci ze školy odnesou (fakta, dovednosti, kompetence), ale jakými se stanou. Jde o celistvost tělesně-psycho-sociálně-spirituální jednoty jejich existence. Naučit se usebrání se sebou samými (logos) a usebrání vlastního logu s logem polis a kosmu, tj. s logem Celku. ${ }^{71}$ Učitel by se měl nechat prostoupit rozporností doby a mít odvahu k syntéze. Vybírat učivo k výkladu textů s ohledem na rozvíjení hodnotové orientace žáků, vychovávat hodnotami k hodnotám. Žák by měl hledat odpovědi na vážné otázky existenciální a etické skrze umění. Umění představuje výsostnou cestu k sobě, obrací se k duši a jejím mohutnostem. Slovy Zdeňka Neubauera: „Probouzí, oslovuje a rozeznívá rozmanité mohutnosti lidské psychiky; promlouvá ze světa, jehož jsme obyvateli, mluví v příbězích, které se sice nestaly, jichž jsme však součástí. " 72

Vyprávění př́iběhů jako bytostně lidský fenomén představuje podle Iva T. Budila antropologickou konstantu lidské existence. ${ }^{73}$ Cestou narace se utvář́i identita člověka. Cit, obraz a slovo

\footnotetext{
65 Jan SOKOL, Slovník filosofických pojmů, Praha: Vyšehrad, 1998, s. 179.

66 Srov. Jan HÁBL, Učit (se) př́během, s. 70.

67 Srov. Zdeněk NEUBAUER, O počátku, cestě a znamení časů, s. 223.

68 Jan PATOČKA, Úvod do fenomenologické filozofie, Praha: OIKOYMENH, 2003, s. 160.

69 Srov. Jan PONĚŠICKÝ, Člověk a jeho postavení ve světě, s. 83.

70 Srov. Zdeněk NEUBAUER, O počátku, cestě a znamení časů, s. 237.

71 Srov. Jan PONĚŠICKÝ, Člověk a jeho postavení ve světě, s. 204.

72 Zdeněk NEUBAUER, Smysl a svět, Praha: Nadace Dagmar a Václava Havlových Vize 97, 2001 , s. 92.

73 Srov. Ivo T. BUDIL, Mýtus, jazyk a kulturní antropologie, Praha: Triton, 2003, s. 277.
} 
je vždy mezi ním a pravým bytím. ${ }^{74}$ Traduje se, že pravda oděná do př́iběhu projde každými dveřmi. Odlesk evangelia proniká vším velkým uměním. A tam, kde v sobě odhalujeme posvátné, tam teprve začínáme být. ${ }^{75}$ Svět reflektovaný učitelem optikou př́iběhů pomáhá nápravě věcí lidských a transcendentnímu zakotvení lidství svých žáků. Příběh jako bezprostřední otisk života otevírá třetí zrak pro transcendentní hodnoty a přibližuje nás sokratovskému ideálu věčného hledačství pravdy, dobra a krásy. Vyprávějme tedy svým dětem a žákům příběhy. Jsou to tvưrčí akty, jimiž tvoříme svět. Je to ten pravý klíč k otevírání tajemství života a lidské existence. Přivádí k podstatě duše, do domu srdce svého. „A srdce má své důvody, o nichž rozum nemá ponětí..." ${ }^{47}$

\section{Chvála vyprávění aneb narativní stezky výchovy k hodnotám}

Abstrakł Studie pojednává o narativní metodě jako možném zpưsobu výchovy k hodnotám. Přiběh a jeho vliv na člověka je od druhé poloviny 20. století jedním z hlavních témat diskuse ve filosofii, teologii, psychologii, literární vědě i v kulturní antropologii. z pedagogického hlediska text zdưrazňuje angažovaný vstup jedince do príběhu $v$ duchu tzv. rehabilitace narativity $v$ didaktickém procesu. Prostřednictvím přiběhu, který umožňuje i v postmoderní době výchovně-vzdělávací pưsobení, Ize dosáhnout celistvosti tělesně-psycho-sociálně-spirituální jednoty existence jedince.

Klíčová slova narativita; narativizace; vyprávění, přiběh; postmoderní společnost; výchova k hodnotám

\section{A Paean to Narration, or Narrative Paths of Educating to Values}

Abstract The paper deals with the narrative method as a possible way of educating to values. The story and its effect on humans has since the second half of the 20th century been a major discussion topic of philosophy, theology, psychology, literary theory and cultural anthropology. From the pedagogical point of view the study emphasizes the reader's involved entering the story in the spirit of so-called rehabilitation of narration in the didactic process. Physical, psychological, social and spiritual integrity of the unity of an individual existence can be attained by means of stories which allow for educational effect even in the postmodern period.

Keywords narrativity; narrativization; story-telling; story; postmodern society; educating to values

74 Srov. Martin BUBER, Já a Ty, Praha: Kalich, 2005, s. 28.

75 Srov. Daniela HODROVÁ, Chvála schoulení (Eseje z poetiky pomíjivosti), Praha: Malvern, 2011, s. 167.

76 Blaise PASCAL, Myšlenky, LXIX, Praha: Mladá fronta, 1973, s. 22. 